\title{
Relationship between body size and sexual size dimorphism in syringophilid quill mites
}

\author{
Lajos Rózsa ${ }^{1}$ Evelyn Moldovan ${ }^{2}$
}

Received: 7 September 2021 / Accepted: 11 January 2022 / Published online: 24 January 2022

(c) The Author(s) 2022

\begin{abstract}
A positive relationship of body size and sexual size dimorphism (males' size relative to females), called Rensch's rule, is often observed in comparisons within non-parasitic taxa. However, this allometric relationship has rarely been tested in comparisons across closely related parasite species. Since male sexual rivalry is often regarded as the main cause of this phenomenon, the present study tests this rule in a taxon where sexual selection is almost totally absent in males. Body size data of (non-physogastric) female and male quill mites (Acari: Syringophilidae) were gathered from the literature to investigate this relationship. The data set consisted of 113 species representing 8 genera. For the data set as a whole, increasing body size came together with decreasing relative body size of males (relative to females), a phenomenon known as converse Rensch's rule. Repeating the same analysis for the 8 genera separately, similar patterns were found in 4 significant and 3 non-significant cases. There was a significant tendency to comply with Rensch's rule only in one genus, the Neoaulonastus. Thus, converse Rensch's rule is the primary trend in syringophilid quill mites that appears repeatedly and independently in several genera. This phenomenon is probably caused by their extreme inbreeding, which strongly reduces sexual competition among males in this taxon.
\end{abstract}

Keywords Quill mites · Sexual selection in parasites · Rensch's rule · Converse Rensch's rule

\section{Introduction}

Most parasites reproduce sexually, or at least both sexually and asexually, giving rise to sexual selection as a potentially influential force on their evolution. However, sexual selection is not easy to measure directly. Most often only its indirect effects are detected, such as the sexually selected morphological traits of parasites. Sexual dimorphism in body size is widespread among dioecious parasites, such as in nematodes, acanthocephalans, gamasid mites, fleas, and lice (see, e.g., Poulin 1997; Caddigan et al. 2017; Surkova et al. 2018; Piross et al. 2019). It is of outstanding importance

Handling Editor: Una Ryan

Lajos Rózsa

rozsa.lajos@ecolres.hu

1 Institute of Evolution, ELKH Centre for Ecological Research, Konkoly-Thege street 29-33, Budapest H-1121, Hungary

2 Hungarian Department of Biology and Ecology, Babeș-Bolyai University, Cluj-Napoca, Romania since body size influences metabolism, length of development, longevity, sexual competitive ability, and fecundity (for insects, see, e.g., Honěk 1993; Waller and Svensson 2017; Beukeboom 2018). Female fecundity likely increases with body size in ectoparasitic arthropods, because larger females can produce more offspring (Villa et al. 2018). Similarly, larger males can produce more sperm than smaller ones, which is an adaptive advantage under the circumstances of sperm competition that characterizes male-male rivalry in many ectoparasitic arthropods (Pap et al. 2013; Rózsa et al. 2015). Moreover, body size data are readily available from the taxonomic literature, such as species descriptions (for ectoparasites, see, e.g., Harnos et al. 2017).

In comparisons across closely related species, male body size relative to female size tends to increase with the average size of the species, an allometric relationship called Rensch's rule (RR). More specifically, RR postulates that sexual size dimorphism decreases with the species body size in taxa where males are smaller than females, and it increases in taxa where males are larger than females (Rensch 1959). Several free-living (i.e., non-parasitic) animals, and most often vertebrates, have been analyzed in this respect, and a 
majority of them proved the validity of RR (see, e.g., Smith and Cheverud 2002; Székely et al. 2004). Nonetheless, opposite trends (where male relative size decreases with the size of the species) also occur in some taxa, a phenomenon known as converse Rensch's rule (ConRR). This trend characterizes, among others, several bird families (Webb and Freckleton 2007).

Although parasitism is a most widespread life strategy in the biosphere (Poulin and Morand 2014), almost all studies on RR or ConRR focus on free-living animals, with very few studies on parasites. Poulin (1996) showed that parasitic copepods follow RR, but parasitic nematodes do not comply (Poulin 1997). Surkova et al. (2018) found that fleas (Siphonaptera) obey, but parasitic gamasid mites disobey RR. Piross et al. (2019) recently showed that two families of avian lice (Menoponidae, Philopteridae) comply with $\mathrm{RR}$, and the third one (Ricinidae) complies with ConRR. The potential reasons for these contradictory patterns are not clearly understood. Since sexual selection (and maleto-male sexual rivalry in particular) is often argued to be the driving force of RR (see, e.g., Székely et al. 2004), it is worth testing its validity in sexually reproducing taxa that are characterized by the absence of sexual selection. RR is predicted not to apply to these taxa.

Syringophilid quill mites constitute a species-rich (406 species in 63 genera up to the present, Zmudzinski et al. 2020) family of prostigmatic mites (Acari: Acariformes: Prostigmata) that are permanently associated with avian (Vertebrata: Aves) feathers. They likely appeared about 180-185 million years ago in the Early Jurassic, presumably on feathered dinosaurs (Dabert et al. 2010). All known representatives of the family inhabit feather quills. Members of the subfamily Syringophilinae tend to inhabit the quills of primaries, secondaries, and wing coverts, while Picobiinae species are found in the quills of body contour feathers (Skoracki et al. 2012a).

They exhibit a remarkable life cycle. A single fertilized female enters the soft calamus of a developing feather through the superior umbilicus (Casto 1974). This opening is getting closed soon, and the female will produce offspring, most often a single male and several females, developing in this enclosed space. The offspring then fertilize each other and produce one more generation still enclosed in the same feather quill. Again, only a single male offspring is produced by each female, which will fertilize their sisters and cousins. Finally, only fertilized females disperse to search for developing feathers either on the same host individual or on another one (Kethley 1971; Skoracki et al. 2012a). The most frequent type of transmission is probably the parentoffspring route.

Given that brothers, sisters, and first cousins tend to fertilize each other, the population structure of quill mites must be highly inbred. On some rare occasions, however, two or more females may invade the same quill to found new subpopulations in parallel (see, e.g., Casto 1974; Skoracki et al. 2020), potentially giving rise to sexual competition and sexual selection between the males. Nevertheless, such events must be rare because of the space limitation within the feather quills. Given that sexual selection is almost totally lacking in this taxon, the objective of this study was to test the predicted absence of RR in quill mites.

\section{Materials and methods}

Different genera that inhabit different microhabitats in the bird plumage were included. Thus, as an arbitrary decision, 9 relatively species-rich genera were chosen for the present analysis: Syringophiloidus, Syringophilopsis, Aulobia, and Torotrogla which infest the secondaries and primaries, Aulonastus and Neoaulonastus which infest the small coverts, and Picobia, Gunabopicobia, and Neopicobia which infest the contour feathers.

The taxonomic literature was not sampled to gather data; instead, every species description ever published was involved. The comprehensive list of species descriptions by Zmudzinski et al. (2020) was used as a starting point for orientation in the literature. The body size data were obtained from the species descriptions of Bochkov (2001), Bochkov and Apanaskevich (2001), Bochkov and Galloway (2001, 2004), Bochkov and Mironov (1998, 1999), Bochkov et al. (2000, 2001, 2004, 2009), Chirov and Kravtsova (1995), Fain et al. (2000), Glowska (2014), Glowska and Skoracki (2011), Glowska et al. (2015, 2018), Kethley (1970), Klimovičová et al. (2016), Nattress and Skoracki (2007), Sikora et al. (2011, 2014, 2016), Skoracki (1999, 2002a, b, 2004a, b, c, 2011, 2017), Skoracki and Bochkov (2010), Skoracki and Dabert (1999, 2000, 2001a, b, 2002), Skoracki and Glowska (2008a, b), Skoracki and Hromada (2013), Skoracki and Magowski (2001), Skoracki and Mironov (2013), Skoracki and O'Connor (2010), Skoracki and Sikora (2003, 2014), and Skoracki et al. (2000b, 2001a, b, 2002, 2003, 2004, 2008a, b, 2010a, b, c, d, 2011, 2012b, 2013a, b, 2014a, b, c, 2016a, b, c, 2017, 2018).

In certain arthropods, there is an alternative female phenotype characterized by a greatly enlarged abdomen (or hysterosoma, in mites) size. These females, called physogastric females, occur together with "normal" females. This phenomenon is well known in the quill mite subfamily Picobiinae but not in Syringophilinae (Skoracki et al. 2012a). Thus, the adult females of the former subfamily may have two alternative phenotypes: the more frequent non-physogastric and the less common physogastric form. The adaptive value of this dimorphism is unknown (Skoracki et al. 2000a). To ensure comparability of body size data across the two 
subfamilies, all physogastric body size data were excluded from the present study.

The majority of species were excluded from the present analyses because either the male or (in rare occasions) the non-physogastric female body length was not known. The genus Gunabopicobia was excluded because it had only a single species where both body length data were available. Further, Torotrogla calcarius Skoracki 2004a, b, c exhibited an unusual characteristic in the sense that the males were larger than the single female known. The author of this species description stated that this female specimen was slightly distorted and its length measurement was likely incorrect (Maciej Skoracki, personal communication); thus, it was also excluded from the data set. Worth noting that, if included, this data point would further increase the statistical significance of results.

The total body length (in micrometers) values were used as a measure of body size. Whenever it was possible, the data of the holotype specimens were used. Otherwise, the mean of the extreme values of the body length range of the series of paratype specimens was calculated. Males are always smaller-sized than females in this taxon. In the present sample of species, female body length ranged between 405 and 1320, and male body length between 270 and 955 $\mu \mathrm{m}$.

Raw data of body length did not vary more than one magnitude and, therefore, logarithmic (or any other) transformation of data was not applied. Following Reiczigel et al. (2014), homoscedasticity of data was tested using the $F$-test, and normality of the residuals was checked using the Shapiro-Wilk test ( $p>0.05$ in all cases). Reduced major axis (RMA) regressions (Legendre 2018) were used to describe how male and female body lengths were correlated. A slope of the regression line $>1$ was considered as a proof of $R R$, and a slope $<1$ as a proof of ConRR. The significance levels were judged using the $95 \%$ of confidence intervals of the slopes.
Closely related species are more likely to share similar characters than distantly related ones. Therefore, when analyzing statistical covariation between two characters across a set of species, it is necessary to control for phylogenetic associations (Felsenstein 1985). In the present case, unfortunately, the phylogeny of syringophilids is not adequately known to apply advanced statistical methods for this purpose. Therefore, this goal was approached by the following simplified way. First, the analysis was carried out using the data of all species regardless of their taxonomic position. Second, the same calculations were carried out for all the genera separately to see if the same pattern is repeated independently. Presuming that the taxonomic classification mirrors the true phylogeny of species, this is regarded as a simplified statistical control for phylogeny.

\section{Results}

The data set contained a total of 113 species belonging to 8 genera that inhabit 3 different microhabitats in the host plumage. As a whole, the data followed ConRR in the sense that the entire $95 \%$ confidence interval of its slope fell within the $0<$ slope $<1$ range. Considering the slopes of the 8 genera separately yielded in roughly similar patterns. Only one genus, namely, Neoaulonastus, exhibited a significant trend to follow RR (slope $>1$ ). Worth noting that this genus also had the lowest sample size (number of species $=6$ ). Independently from each other, all the other genera followed ConRR, and this trend was significant in 4 and non-significant in 3 cases (Table 1, Fig. 1).

The eight slopes of the genus-level RMA regression models had a mean of 0.739 that differs significantly (one-sample $t$-test, $t=2.914, \mathrm{df}=7, p=0.022$ ) from the hypothetical value of 1 (which would signify no relationship between body size and sexual size dimorphism).
Table 1 Reduced major axis regression models for the relationship between female body length and male body length for the whole family of quill mites and for 8 genera separately. Slopes $<1$ indicate agreement with ConRR, while slopes $>1$ indicate agreement with RR

\begin{tabular}{llllllll}
\hline Taxon & $N$ species & $R^{2}$ & Slope & $95 \%$ CI lower & $95 \%$ CI upper & Trend & $\begin{array}{l}\text { Signifi- } \\
\text { cance } \\
95 \%\end{array}$ \\
\hline Syringophilidae & 113 & 0.851 & 0.689 & 0.640 & 0.741 & ConRR & S \\
Aulonastus & 8 & 0.470 & 0.795 & 0.405 & 1.560 & ConRR & NS \\
Torotrogla & 11 & 0.416 & 0.693 & 0.400 & 1.199 & ConRR & NS \\
Neoaulonastus & 6 & 0.971 & 1.281 & 1.014 & 1.617 & RR & S \\
Aulobia & 10 & 0.606 & 0.811 & 0.496 & 1.326 & ConRR & NS \\
Neopicobia & 7 & 0.768 & 0.452 & 0.266 & 0.766 & ConRR & S \\
Picobia & 14 & 0.373 & 0.504 & 0.312 & 0.814 & ConRR & S \\
Syringophiloidus & 25 & 0.524 & 0.725 & 0.541 & 0.973 & ConRR & S \\
Syringophilopsis & 32 & 0.505 & 0.651 & 0.502 & 0.844 & ConRR & S \\
\hline
\end{tabular}


Fig. 1 Male body length as a function of female body length in 113 species of syringophilid quill mites. Each dot indicates a species, and the different genera are not differentiated. RMA regression lines of the eight genera are indicated separately. Solid lines signify those that differ from slope $=1$ significantly $(p<0.05)$. Their slopes are $<1$ indicating that they comply ConRR, with the exception of Neoaulonastus which complies RR (slope > 1). Dashed lines signify genera that comply ConRR non-significantly $(p>0.05)$

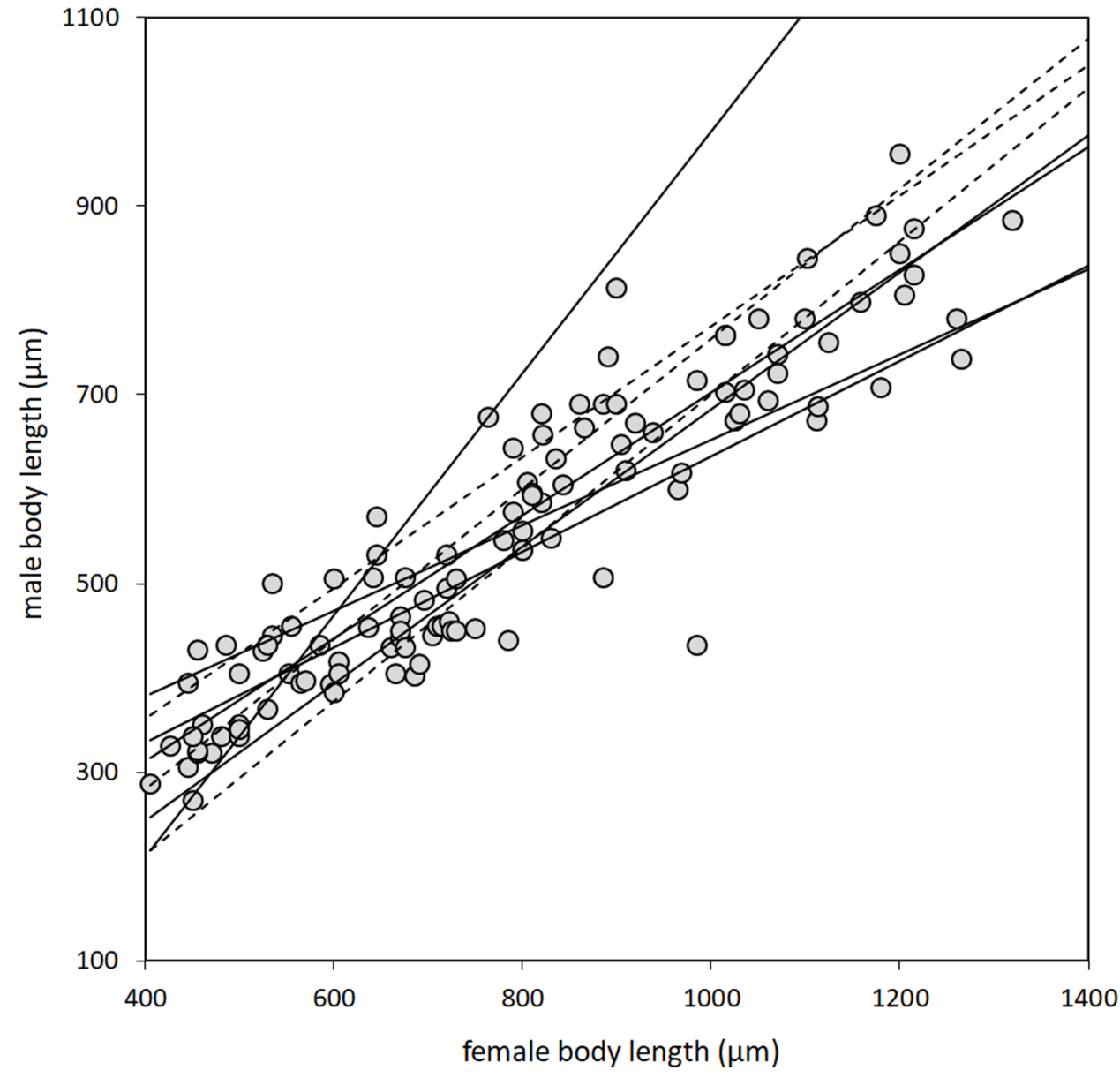

\section{Discussion}

As demonstrated above, ConRR characterizes the family quill mites (Syringophilidae) as a whole. It is not a phylogenetic artifact, rather a phenomenon that appears repeatedly and independently across several, if not all, quill mite genera. Published interpretations of RR and ConRR are diverse and often contradicting, as summarized by Piross et al. (2019). One possible explanation of the present results is outlined below.

Increasing body size is likely to come with increasing costs and benefits for females. First, larger females evidently occupy more space and consume more food to develop and maintain their bodies, decreasing the space and other resources available for their own siblings and offspring. Due to their increased metabolism, presumably, larger bodies evoke more intensive host defenses, such as more intense immune response or more intense preening and grooming while the mite is out of the quill. These factors likely constitute increased costs of larger body sizes. On the other hand, larger females likely enjoy a reproductive benefit; they can probably produce a greater number and largersized offspring (like in feather lice, see Villa et al. 2018). In male individuals, the potential costs of larger body size are similar to that of females; more space occupied, more food consumed, and more defensive responses evoked. The potential benefits of larger male body size, however, are (almost) absent. Given that sexual rivalry is almost totally absent in males, larger size does not ensure a reproductive advantage in the male sex. This is a possible reason why the increase of female body size is not followed by a comparable increase of male body size in syringophilid quill mites. This interpretation corresponds the so-called sexual selection hypothesis of RR (Fairbairn and Preziosi 1994; Fairbairn 1997).

If this explanation is correct, it may also support the recent results and interpretations of Piross et al.'s (2019) study on avian lice (Phthiraptera). Among avian lice, only one family, the Ricinidae, complied with ConRR. Note that this family possesses the largest body size relative to the host body size (Harnos et al. 2017). Therefore, only a few individuals may occur on an individual host. Moreover, their prevalence also tends to be low (Rheinwald 1968; Nelson 1972), and thus, multiple infestations are necessarily rare. These factors make it likely that inbreeding is high in ricinid lice, a presumption also supported by the relatively low sexratio (proportion of males) in this family. 
Briefly, the present results suggest that parasite taxa with pronounced inbreeding and, therefore, reduced male-male competition are predicted to comply with ConRR, rather than RR.

Acknowledgements We thank Bożena Sikora and Maciej Skoracki for their help to gather the species descriptions and their comments on a previous version of the manuscript.

Funding Open access funding provided by ELKH Centre for Ecological Research. Open access funding was provided by the Hungarian Academy of Sciences, MTA.

Data availability Not applicable.

Code availability Not applicable.

\section{Declarations}

Ethics approval Not applicable.

Consent to participate Not applicable.

Consent for publication Not applicable.

Conflict of interest The authors declare no competing interests.

Open Access This article is licensed under a Creative Commons Attribution 4.0 International License, which permits use, sharing, adaptation, distribution and reproduction in any medium or format, as long as you give appropriate credit to the original author(s) and the source, provide a link to the Creative Commons licence, and indicate if changes were made. The images or other third party material in this article are included in the article's Creative Commons licence, unless indicated otherwise in a credit line to the material. If material is not included in the article's Creative Commons licence and your intended use is not permitted by statutory regulation or exceeds the permitted use, you will need to obtain permission directly from the copyright holder. To view a copy of this licence, visit http://creativecommons.org/licenses/by/4.0/.

\section{References}

Beukeboom LW (2018) Size matters in insects - an introduction. Entomol Exp Appl 166:2-3. https://doi.org/10.1111/eea.12646

Bochkov AV (2001) On the taxonomy of mites of the genus Syringophiloidus Kethley, 1970 (Acari: Syringophilidae) of European part of the Russia. Parasitologya 35:149-153

Bochkov AV, Apanaskevich D (2001) Two new species of the family Syringophilidae (Acari: Cheyletoidea) from passeriform birds collected in the Altai. Folia Parasit 48:321-325 https://doi.org/ 10.14411/fp.2001.050

Bochkov AV, Galloway TD (2001) Parasitic cheyletoid mites (Acari: Cheyletoidea) associated with passeriform birds (Aves: Passeriformes) in Canada. Can J Zool 79:2014-2028. https://doi.org/10. 1139/cjz-79-11-2014

Bochkov AV, Galloway TD (2004) New species and records of cheyletoid mites (Acari: Cheyletoidea) from birds in Canada. J Kansas Entomol Soc 77:26-44. https://doi.org/10.2317/0211.01.1
Bochkov AV, Mironov SV (1998) Quill mites of the family Syringophilidae Lavoipierre, 1953 (Acariformes: Prostigmata) parasitic on birds (Aves) of the fauna of the former USSR. Acarina 6:3-16

Bochkov AV, Mironov SV (1999) New quill mite species of the family Syringophilidae (Acari: Cheyletoidea) from the European part of Russia. Acarina 7:35-45

Bochkov AV, Mironov SV, Kravtsova NT (2000) Two new syringophilid mites from the greenfinch Carduelis chloris (Passeriformes: Fringillidae) from Kirghizia (Acari: Syringophilidae). Genus 11:351-358

Bochkov AV, Mironov SV, Skoracki M (2001) Four new quill mite species of the genus Syringophilopsis Kethley, 1970 (Acariformes: Prostigmata). Acarina 9:233-239

Bochkov AV, Fain A, Skoracki M (2004) New quill mites of the family Syringophilidae (Acari: Cheyletoidea). Syst Parasitol 57:135-150. https://doi.org/10.1023/B:SYPA.0000013858.86399.69

Bochkov AV, Flannery ME, Spicer GS (2009) Mites of the genus Torotrogla (Prostigmata: Syringophilidae) from North American passerines. J Med Entomol 46:183-197. https://doi.org/10. 1603/033.046.0203

Caddigan SC, Pfenning AC, Sparkes TC (2017) Competitive growth, energy allocation, and host modification in the acanthocephalan Acanthocephalus dirus: field data. Parasitol Res 116:199-206. https://doi.org/10.1007/s00436-016-5279-8

Casto SD (1974) Entry and exit of syringophilid mites (Acarina: Syringophilidae) from the lumen of the quill. Wilson Bull 86:272-278

Chirov PA, Kravtsova NT (1995) A new genus and new species of mites of the family Syringophilidae. Parazitologiya 29:370-379

Dabert M, Witalinski W, Kazmierski A, Olszanowski Z, Dabert J (2010) Molecular phylogeny of acariform mites (Acari, Arachnida): strong conflict between phylogenetic signal and longbranch attraction artifacts. Mol Phylogenet Evol 56(1):222-241. https:// doi.org/10.1016/j.ympev.2009.12.020

Fain A, Bochkov AV, Mironov SV (2000) New genera and species of quill mites of the family Syringophilidae (Acari: Prostigmata). Bull Inst Sci Nat Belg, Entomol 70:33-70

Fairbairn DJ (1997) Allometry for sexual size dimorphism: pattern and process in the coevolution of body size in males and females. Annu Rev Ecol Syst 28:659-687. https://doi.org/10.1146/annur ev.ecolsys.28.1.659

Fairbairn DJ, Preziosi RF (1994) Sexual selection and the evolution of allometry for sexual size dimorphism in the water strider, Aquarius remigis. Am Nat 144:101-118. https://doi.org/10.1086/285663

Felsenstein J (1985) Phylogenies and the comparative method. Am Nat 125:1-15. https://doi.org/10.1086/284325

Glowska E (2014) New quill mites (Cheyletoidea: Syringophilidae) parasitizing tyrannid birds (Passeriformes: Tyrannidae) in Peru. Zootaxa 3814(1):139-145 https://doi.org/10.11646/zootaxa. 3814.1.9

Glowska E, Skoracki M (2011) New species of quill mites (Acari, Cheyletoidea, Syringophilidae) and the first record of male for the genus Stibarokris. Zootaxa 2817:63-68

Glowska E, Laniecka I, Milensky CM (2015) Two new picobiin mite species (Acari: Cheyletoidea: Syringophilidae) parasitizing passerine birds in Guyana. Acta Parasitol 60(3):488-493. https://doi. org/10.1515/ap-2015-0069

Glowska E, Romanowska K, Schmidt BK, Dabert M (2018) Combined description (morphology with DNA barcodedata) of a new quill mite Torotrogla paenae n. sp. (Acariformes: Syringophilidae) parasitising the Kalahari scrub-robin Cercotrichas paena (Smith) (Passeriformes: Muscicapidae) in Namibia. Syst Parasitol 95:863869. https://doi.org/10.1007/s11230-018-9815-z

Harnos A, Lang Z, Petrás D, Bush SE, Szabó K, Rózsa L (2017) Size matters for lice on birds: coevolutionary allometry of host and 
parasite body size. Evolution 71:421-431. https://doi.org/10.1111/ evo. 13147

Honěk A (1993) Intraspecific variation in body size and fecundity in insects: a general relationship. Oikos 66:483-492. https://doi.org/ $10.2307 / 3544943$

Kethley JB (1970) A revision of the family Syringophilidae (Prostigmata: Acarina). Contrib Am Entomol Inst 5:1-76

Kethley JB (1971) Population regulation in quill mites (Acarina: Syringophilidae). Ecology 52(6):1113-1118. https://doi.org/10.2307/ 1933821

Klimovičová M, Skoracki M, Njoroge P, Hromada M (2016) Two new species of the family Syringophilidae (Prostigmata: Syringophilidae) parasitising bushshrikes (Passeriformes: Malaconotidae). J Parasitol 102(2):187-192. https://doi.org/10.1645/15-870

Legendre P (2018) Package 'lmodel2'. R library. Available online at: https://cran.r-project.org/web/packages/lmodel2/index.html. Accessed: January 5, 2021

Nattress B, Skoracki M (2007) Quill mites of the family Syringophilidae Lavoipierre, 1953 (Acari: Cheyletoidea) parasitic on birds in England. Genus 18:139-145

Nelson BC (1972) A revision of the New World species of Ricinus (Mallophaga) occurring on Passeriformes (Aves). UC Publ Entomol 68:1-175

Pap PL, Adam C, Vágási CI, Benkő Z, Vincze O (2013) Sex ratio and sexual dimorphism of three lice species with contrasting prevalence parasitizing the house sparrow. J Parasitol 99(1):24-30. https://doi.org/10.1645/GE-3157.1

Piross IS, Harnos A, Rózsa L (2019) Rensch's rule in avian lice: contradictory allometric trends for sexual size dimorphism. Sci Rep 9:7908. https://doi.org/10.1038/s41598-019-44370-5

Poulin R (1996) Sexual size dimorphism and transition to parasitism in copepods. Evolution 50:2520-2523. https://doi.org/10. 2307/2410720

Poulin R (1997) Covariation of sexual size dimorphism and adult sex ratio in parasitic nematodes. Biol J Linn Soc 62:567-580. https://doi.org/10.1006/bijl.1997.0167

Poulin R, Morand S (2014) Parasite biodiversity. Smithsonian Institution, Washington, DC

Reiczigel J, Harnos A, Solymosi N (2014) Biostatisztika nem statisztikusoknak [Biostatistics for non statisticians], 3rd edn. Pars Ltd., Budapest (in Hungarian)

Rensch B (1959) Evolution above the species level. Methuen and Co., Ltd., London

Rheinwald G (1968) Die Mallophagengattung Ricinus De Geer, 1778. Revision der ausseramerikanischen Arten. Mitt Hamburg Zool Mus Inst 65:181-326

Rózsa L, Tryjanowski P, Vas Z (2015) Under the changing climate: how shifting geographic distributions and sexual selection shape parasite diversification. In: Morand S, Krasnov B, Littlewood T (eds) Parasite diversity and diversification: evolutionary ecology meets phylogenetics. Cambridge University Press, Cambridge, pp 58-76

Sikora B, Fajfer M, Skoracki M (2011) Quill mites (Acari: Syringophilidae) from mimid birds (Aves: Mimidae). Zootaxa 3027:29-38

Sikora B, Kaszewska K, Skoracki M (2014) Two new quill mites of the family Syringophilidae (Acari: Prostigmata) parasitising the tapaculos (Passeriformes: Rhinocriptidae) in South America. Zootaxa 3895(3):419-426 https://doi.org/10.11646/zootaxa. 3895.3.6

Sikora B, Unsöld M, Skoracki M (2016) Aulonastus paridus spec. nov. - a parasite of two bird species of the genus Melaniparus in Kenya and Tanzania. Spixiana 39(2):149-152.

Skoracki M (1999) New genus and species of Syringophilidae from Eurasian reed-warbler, Acrocephalus scirpaceus (Sylviidae: Passeriformes) (Acari: Prostigmata). Genus 10:155-162
Skoracki M (2002) Three new species of quill mites of the genus Aulonastus Kethley, 1970 (Acari, Prostigmata, Syringophilidae) from passerine birds. Acta Parasitol 47:300-305

Skoracki M (2002b) Three new species of the ectoparasitic mites of the genus Syringophiloidus Kethley, 1970 (Acari: Syringophilidae) from passeriform birds from Slovakia. Folia Parasit 49:305-313 https://doi.org/10.14411/fp.2002.057

Skoracki M (2004) A review of quill mites of the genus Syringophiloidus Kethley, 1970 parasitizing quills of passeriform birds, with descriptions of four new species (Acari: Prostigmata: Syringophilidae). Genus 15:281-300

Skoracki M (2004) Quill mites of the genus Syringophilopsis (Acari, Syringophilidae) from passeriform birds of Poland with descriptions of five new species. Acta Parasitol 49:45-62

Skoracki M (2004) New data on systematics of the quill mites of the genus Torotrogla Kethley, 1970 (Acari: Syringophilidae). Belg J Entomol 6:303-314

Skoracki M (2011) Quill mites (Acari: Syringophilidae) of the Palaearctic region. Zootaxa 2840:1-414

Skoracki M (2017) Quill mites (Acariformes: Syringophilidae) associated with birds of Mexico. Zootaxa 4282(1):179-191 https://doi. org/10.11646/zootaxa.4282.1.11

Skoracki M, Bochkov AV (2010) Syringophilid mites from Kazakhstan. Zootaxa 2546:52-68

Skoracki M, Dabert M (1999) A new species of the genus Syringophilopsis Kethley, 1970 (Acari: Prostigmata: Syringophilidae) from the tree pipit Anthus trivialis (Passeriformes: Motacillidae). Acarina 7:89-92

Skoracki M, Dabert M (2000) Syringophilopsis albicollisi sp.n., a new species of the quill mite of the family Syringophilidae (Acari: Prostigmata). Acarina 8:59-63

Skoracki M, Dabert M (2001) The quill mites of the genus Syringophilopsis Kethley, 1970 (Acari: Syringophilidae) from African birds. Acarina 9:105-112

Skoracki M, Dabert M (2001) Two new species of the parasitic mites of the genus Aulobia Kethley, 1970 (Acari, Syringophilidae) from African birds. Acta Parasitol 46:208-215

Skoracki M, Dabert M (2002) A review of parasitic mites of the family Syringophilidae (Acari, Prostigmata) from African birds, with descriptions of four new species. Acta Parasitol 47:137-146

Skoracki M, Glowska E (2008a) Two new species of the quill mite genus Aulobia Kethley, 1970 (Acari, Syringophilidae) associated with sunbirds (Passeriformes, Nectariniidae). Acta Parasitol 53:179-185. https://doi.org/10.2478/s11686-008-0022-y

Skoracki M, Glowska E (2008b) Two new species of the genus Picobia Haller (Acari: Syringophilidae) from Australian and Indonesian passeriform birds. New Zeal J Zool 35:281-286. https://doi.org/ 10.1080/03014220809510125

Skoracki M, Hromada M (2013) A review of picobiine mites (Acari: Syringophilidae: Picobiinae) parasitising African birds. Folia Parasit 60:192-212 https://doi.org/10.14411/fp.2013.022.

Skoracki M, Magowski W (2001) Two new species of quill mites of the genus Picobia (Acari: Prostigmata: Syringophilidae) from passerine birds of Poland. Acarina 9:113-119

Skoracki M, Mironov SV (2013) New species and records of quill mites of the family Syringophilidae (Acari: Prostigmata) from the passerines (Aves: Passeriformes) from the Russian Far East. Zootaxa 3641(5):554-564 https://doi.org/10.11646/zootaxa.3641.5.4

Skoracki M, O'Connor B (2010) New taxa of quill mites (Acari: Cheyletoidea: Syringophilidae). Zootaxa 2341:1-32

Skoracki M, Sikora B (2003) Quill mites (Acari: Prostigmata: Syringophilidae) from African passeriform birds. Zootaxa 129:1-10

Skoracki M, Sikora B (2014) Two new quill mite species of the family Syringophilidae (Acari: Prostigmata) parasitising the house sparrow Passer domesticus (L.) (Aves: Passeriformes). Zootaxa 3765(2):194-200 https://doi.org/10.11646/zootaxa.3765.2.7 
Skoracki M, Magowski W, Dabert J (2000a) Picobia polonica sp. n. (Acari: Prostigmata: Syringophilidae), a new species of quill mite from the domestic hen, Gallus gallus domesticus (Aves: Phasianidae). Folia Parasit 48:154-158 https://doi.org/10.14411/fp.2001. 024

Skoracki M, Dabert M, Ehrnsberger R (2000b) A new quill mite (Acari: Syringophilidae) from the blackbird. Osnabrucker Naturwissenschaftliche Mitteilungen 26:191-198

Skoracki M, Hromada M, Kuczynski L (2001a) Torotrogla lullulae, a new species of the family Syringophilidae Lavoipierre, 1953 (Acari: Prostigmata: Cheyletoidea). Genus 12:87-92

Skoracki M, Hromada M, Tryjanowski P (2001b) Description of a new species of quill mite Syringophiloidus weiszii sp. n. (Acari, Prostigmata, Syringophilidae) from great grey shrike Lanius excubitor. Acta Parasitol 46:30-34

Skoracki M, Tryjanowski P, Hromada M (2002) Two new species of the genus Syringophilopsis Kethley, 1970 (Acari: Syringophilidae) parasitizing quills of true shrikes (Aves: Laniidae). Parasite 9:11-16. https://doi.org/10.1051/parasite/200209111

Skoracki M, Møller AP, Tryjanowski P (2003) A new species of parasitic mites of the genus Syringophiloidus Kethley, 1970 (Acari: Syringophilidea) from the barn swallow Hirundo rustica Linnaeus, 1758. Parasite 10:17-20. https://doi.org/10.1051/parasite/ 2003101 p17

Skoracki M, Bochkov AV, Wauthy G (2004) Revision of the quill mites of the genus Picobia Haller, 1878 (Acari: Syringophilidae) with notes on their host-parasites relationships. Insect Syst Evol 35:155-176. https://doi.org/10.1163/187631204788912409

Skoracki M, Flannery ME, Spicer GS (2008a) Quill mites of the genus Syringophilopsis Kethley, 1970 (Acari: Syringophilidae) from North American birds. Folia Parasit 55:291-300 https://doi.org/ 10.14411/fp.2008.037

Skoracki M, Glowska E, Sikora B (2008b) Four new species of the quill mite genus Picobia Haller (Acari: Syringophilidae) parasitizing birds in the Australian region. Zootaxa 1961:58-68

Skoracki M, Glowska E, Lontkowski J, Stawarczyk T (2010a) Picobia ictericus sp. n., an ectoparasite of two icterid bird species from Brazil (Acari: Prostigmata: Syringophilidae). Genus 21(1):143-148

Skoracki M, Hendricks S, Spicer GS (2010b) Systematics of the ectoparasitic quill mites of the genus Aulobia Kethley, 1970 (Acari: Syringophilidae) with the description of a new species. Zootaxa 2399:31-41

Skoracki M, Hendricks S, Spicer GS (2010c) Four new species of Aulonastus Kethley, 1970 (Acari: Syringophilidae) from North American passerines. Syst Parasitol 76:131-144. https://doi.org/ 10.1007/s11230-010-9240-4

Skoracki M, Hendricks S, Spicer GS (2010d) New species of parasitic quill mites of the genus Picobia (Acari: Syringophilidae: Picobiinae) from North American birds. J Med Entomol 47:727-742. https://doi.org/10.1603/ME09265

Skoracki M, Hendricks S, Spicer GS (2011) Systematics of the genus Syringophilopsis Kethley, 1970 (Acari: Prostigmata: Syringophilidae) with description of three new species from North American passerines. Zootaxa 2793:1-22

Skoracki M, Bochkov AV, Zabludovskaya SA (2012a) A review of Prostigmata (Acariformes: Trombidiformes) permanently associated with birds. Acarina 20(2):67-107

Skoracki M, Solarczyk P, Sikora B (2012b) Three new species of picobiine mites (Acari: Syringophilidae) parasitizing African flycatchers (Aves: Muscicapidae). Syst Parasitol 83:123-135. https://doi. org/10.1007/s11230-012-9376-5

Skoracki M, Hromada M, Unsoeld M (2013a) Three new quill mite species of the genus Neoaulonastus Skoracki (Acari: Syringophilidae) parasitizing passerines in Tanzania. Zootaxa 3616(4):367-377 https://doi.org/10.11646/zootaxa.3616.4.5
Skoracki M, Mironov SV, Unsoeld M (2013b) The first records of quill mites of the family Syringophilidae (Acariformes: Prostigmata: Cheyletoidea) from trogoniform birds (Aves: Trogoniformes). Zootaxa 3701 (2):291-297 https://doi.org/10.11646/zootaxa. 3701.2.9

Skoracki M, Klimovičová M, Muchai M, Hromada M (2014a) New taxa of the family Syringophilidae (Acari: Prostigmata) from the African barbets and woodpeckers (Piciformes: Lybiidae, Picidae). Zootaxa 3768(2):178-188 https://doi.org/10.11646/zoota xa.3768.2.5

Skoracki M, Spicer GS, O'Connor BM (2014b) A review of mites of the subfamily Picobiinae Johnston and Kethley, 1973 (Prostigmata: Syringophilidae) from North American birds. Syst Parasitol 87:99-110. https://doi.org/10.1007/s11230-013-9460-5

Skoracki M, Unsoeld M, Kavetska K, Kaszewska K (2014c) Quill mites of the subfamily Picobiinae (Acari: Syringophilidae) associated with woodpeckers (Aves: Piciformes: Picidae). Acta Parasitol 59:68-79. https://doi.org/10.2478/s11686-014-0210-x

Skoracki M, OConnor BM, Goodman SM, Marciniak N, Sikora B (2016a) New species and records of syringophilid mites (Acariformes: Syringophilidae) associated with Malagasy birds. Syst Appl Acarol 21(11):1534-1546 https://doi.org/10.11158/saa.21. 11.9

Skoracki M, Sikora B, Spicer GS (2016b) A review of the subfamily Picobiinae Johnston and Kethley, 1973 (Acariformes: Prostigmata: Syringophilidae). Zootaxa 4113(1):1-95 https://doi.org/ 10.11646/zootaxa.4113.1.1

Skoracki M, Spicer GS, OConnor BM (2016c) A systematic review of the subfamily Syringophilinae (Acari: Syringophilidae) of the Nearctic region. Part 1: quill mites associated with passerines (Aves: Passeriformes). Zootaxa 4084(4):451-494 https://doi.org/ 10.11646/zootaxa.4084.4.1

Skoracki M, Sikora B, Marciniak N, Zmudzinski M (2017) Syringophiloidus bucerotidus sp. nov. (Acari: Syringophilidae), a new quill mite species parasitizing hornbills (Aves: Bucerotidae) in the Sub-Saharan Africa. Int J Acarol 43(1):39-43 https://doi.org/ 10.1080/01647954.2016.1216598

Skoracki M, Hromada M, Zmudzinski M, Unsoeld M, Sikora B (2018) Parasitic quill mites of the family Syringophilidae (Acariformes: Prostigmata) associated with sub-Saharan sunbirds (Passeriformes: Nectariniidae): species composition and host-parasite relationships. J Med Entomol 55(6):1464-1477. https://doi.org/ 10.1093/jme/tjy106

Skoracki M, Hromada M, Kaszewska K, Sikora B (2020) Females of the quill mite genera Peristerophila and Castosyringophilus (Acariformes: Syringophilidae) are two morphological forms: ontogenetic and population evidences. Syst Appl Acarol 25(10):18031820 https://doi.org/10.11158/saa.25.10.6

Smith RJ, Cheverud JM (2002) Scaling of sexual dimorphism in body mass: a phylogenetic analysis of Rensch's rule in primates. Int J Primatol 23:1095-1135. https://doi.org/10.1023/A:1019654100 876

Surkova EN, Korallo-Vinarskaya NP, Vinarski MV et al (2018) Sexual size dimorphism and sex ratio in arthropod ectoparasites: contrasting patterns at different hierarchical scales. Int J Parasitol 48(12):969-978. https://doi.org/10.1016/j.ijpara. 2018.05.006

Székely T, Freckleton RP, Reynolds JD (2004) Sexual selection explains Rensch's rule of size dimorphism in shorebirds. Proc Natl Acad Sci USA 101:12224-12227. https://doi.org/10.1073/ pnas.0404503101

Villa SM, Evans MD, Subhani YK, Altuna JC, Bush SE, Clayton DH (2018) Body size and fecundity are correlated in feather lice (Phthiraptera: Ischnocera): implications for Harrison's rule. Ecol Entomol 43:394-396. https://doi.org/10.1111/een.12511 
Waller JT, Svensson EI (2017) Body size evolution in an old insect order: no evidence for Cope's rule in spite of fitness benefits of large size. Evolution 71(9):2178-2193. https://doi.org/10.1111/ evo.13302

Webb TJ, Freckleton RP (2007) Only half right: species with femalebiased sexual size dimorphism consistently break Rensch's rule. PLoS ONE 2(9):e897. https://doi.org/10.1371/journal.pone.00008 97
Zmudzinski M, Skoracki M, Sikora B (2020) An updated checklist of quill mites of the family Syringophilidae (Acariformes: Prostigmata): v2020. https://sites.google.com/site/syringophilidae/. Accessed 27 August 2021

Publisher's Note Springer Nature remains neutral with regard to jurisdictional claims in published maps and institutional affiliations. 